\title{
Earthquake swarms in Greenland
}

\author{
Tine B. Larsen, Peter H. Voss, Trine Dahl-Jensen and Hans Peter Rasmussen
}

Two earthquake swarms have been detected in Greenland. One occurred on the island of Disko in August 2010, the other one was active from January 2008 to June 2009 near the South-East Greenland coast $c .200 \mathrm{~km}$ south of Tasiilaq. An earthquake swarm is defined as a series of earthquakes of similar magnitude located within a small area. The magnitude of the largest earthquakes in a swarm is typically less than 4 (Ma \& Eaton 2009). Swarm activity is distinctly different from the more common mainshock-aftershock activity, which is characterised by one large earthquake (mainshock) followed by a series of smaller aftershocks. Earthquake swarms mainly occur in areas with tectonic and/or volcanic activity (Stykes 1970), but intraplate swarms are also found in otherwise stable environments (Gregersen 1979; Atakan et al. 1994; Uski et al. 2006; Ma \& Eaton 2009). Geological boundaries and old fault zones appear to be a common setting for intraplate earthquake swarms. Earthquake swarms have previously been detected in North and North-East Greenland (Gregersen 1979) at a time when the seismograph coverage was very sparse. It was concluded that the earthquake swarms were caused by tectonic stresses in and around old sedimentary basins near the continental margin.

In this study we take advantage of the recently improved network of digital broadband seismographs in Greenland (Dahl-Jensen et al. 2010). The shorter distance between seismograph stations and the high quality digital data enable us to better detect small earthquakes. We have focused on the last decade during which the digital network has gradually been established (Fig. 1). We revisited the two regions where swarms have previously been detected, in North Greenland and in North-East Greenland (Gregersen 1979). Searching the GEUS earthquake database for recent earthquakes showed nothing in the area of the North Greenland swarm. The swarm described by Gregersen (1979) was primarily detected using data from a Canadian station (ALE) and a temporary station on the ice sheet, supplemented with data from Station Nord (NOR) for the largest earthquakes in the swarm. This particular region has not experienced an increase in station coverage in recent years. It is therefore impossible to distinguish whether the lack of recent detections is due to a lack of activity in that area. The location of the North-East Greenland earthquake swarm has also been searched without finding any new swarm activity in the last decade. Only two small earthquakes have been detected in the area, one in 2008 and another in 2011. In this area the station coverage has improved since 1974, so the lack of detections reflects that the area is currently seismically quiet.

Two new localities with earthquake swarms were uncovered in this study (Fig. 1). Both are areas with regular seismic activity. One swarm is located on the island of Disko near the Disko Gneiss Ridge (Fig. 2) where a fault zone runs N-S through the island (Chalmers et al. 1999). This is a very distinct swarm with its main activity concentrated on two days

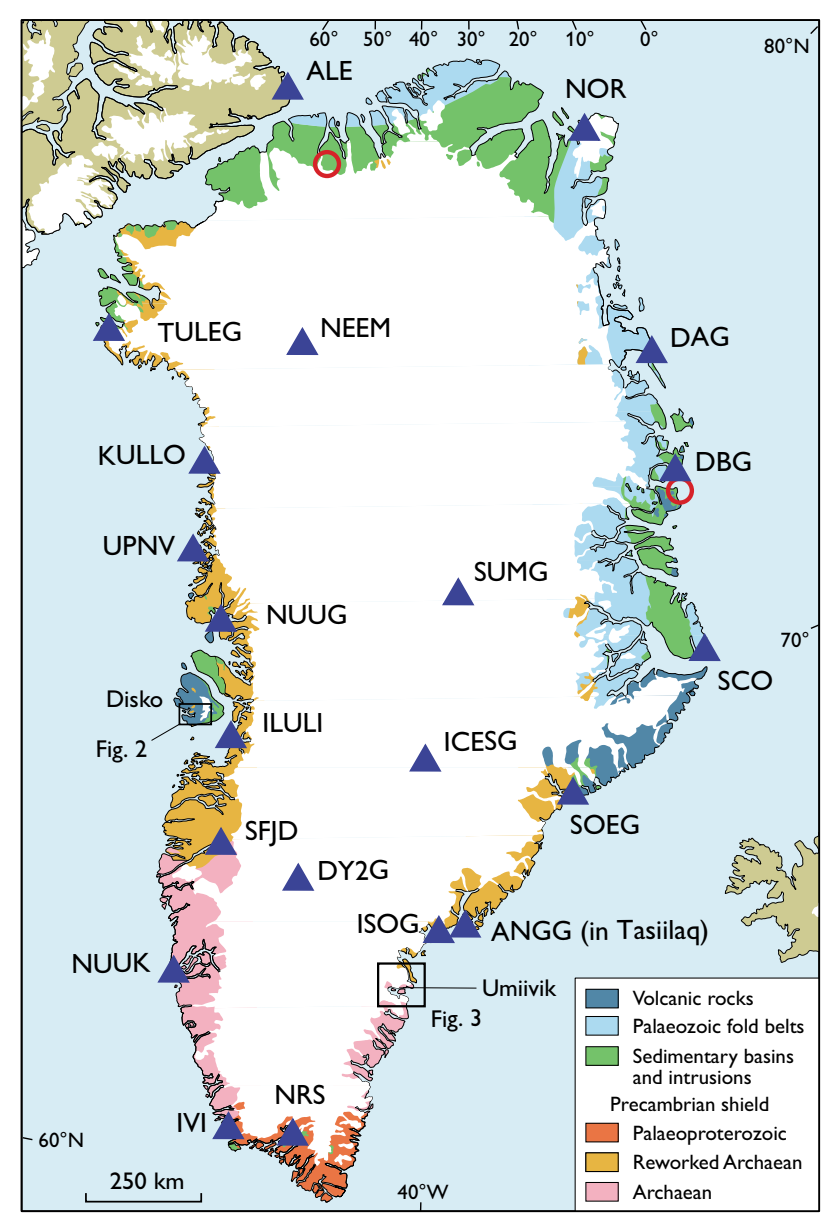

Fig. 1. Geological map of Greenland with seismograph stations marked by triangles. The locations of the swarms found by Gregersen (1979) are marked with red circles. The locations of the swarms presented in this study are marked with black boxes. 


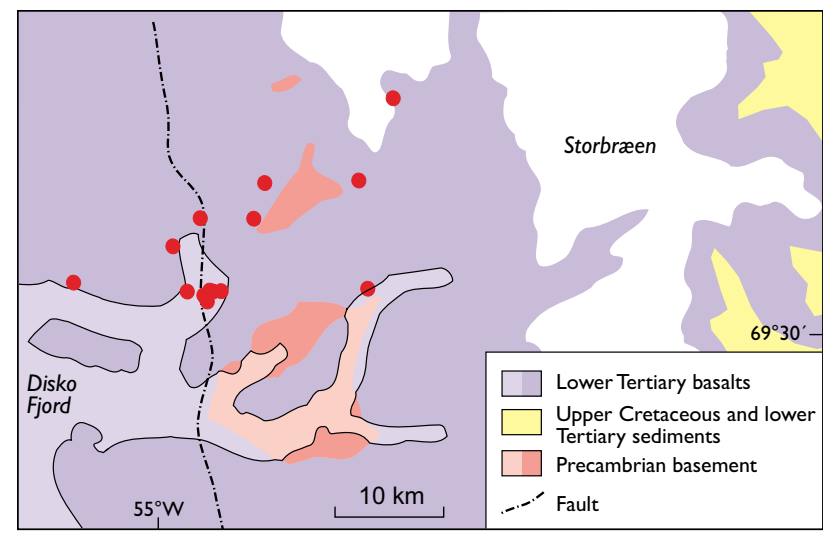

Fig. 2. The calculated epicentres for the swarm earthquakes on Disko, West Greenland. The Disko Gneiss Ridge runs along the fault line on the map.

in late August 2010, followed by slightly increased seismicity during the following two months. The other swarm is located in a remote area near the South-East Greenland coast, c. $200 \mathrm{~km}$ south of Tasiilaq (Fig. 3). This swarm is less distinct with two main pulses of activity in January 2008 and spring 2009. This area had increased seismicity for a year and a half, before it tapered off. The objective of this paper is to describe the two newly discovered earthquake swarms and how they relate to the local geology.

\section{Data and analysis}

Seismographs have been continuously operating in Greenland since 1927 (Hjelme 1996). Originally the instruments were large, difficult to install and labour intensive to maintain. It was only possible to operate a few stations in Greenland. This changed with the development of digital instruments, and during the last decade a network of 20 digital broadband seismographs with real-time data transmission has been installed in Greenland (Fig. 1). This massive undertaking is a result of the international collaboration in the Greenland Ice Sheet Monitoring Network (GLISN) project with funding from around the world (Dahl-Jensen et al. 2010). The latest seismological station was installed in Upernavik in 2013 by the Korean Polar Research Institute (see UPNV Fig. 1).

Data from the real-time network of seismographs are processed daily at GEUS using the SEISAN analysis software (Ottemöller et al. 2013). Earthquake phases are manually identified and combined to form earthquake locations when possible. Locations and phase readings are kept in the GEUS database for future reference. This includes phase readings not associated with an earthquake location. All the raw waveform data are also stored. The new earthquake swarms were discovered by performing a search in the database around locations, where clustering of seismicity was observed on a map of all earthquakes in Greenland. The search results were then examined for possible clustering of events in time. Two earthquake clusters fulfilled the criteria defining an earthquake swarm. Despite the improved station coverage, it is still challenging to determine the focal mechanism of most earthquakes in Greenland. Particularly the small swarm earthquakes that are only registered on one to four seismographs, which is insufficient for reliable focal mechanism calculations.

\section{Earthquake swarm at the island of Disko}

Disko and the surrounding areas are frequently shaken by small earthquakes, some large enough to be felt by the locals. Disko is also known for its warm springs formed where circulating surface water penetrates into the subsurface through deep cracks and is heated by the higher temperatures at depth. The flow of a warm spring is sometimes changed by a small earthquake, indicating that the earthquake sources are shallow. There are thousands of springs with constant temperature on Disko. The temperatures in individual springs vary between $1^{\circ} \mathrm{C}$ and $18.5^{\circ} \mathrm{C}$ (Kristensen 2006).

The number of earthquakes detected near the southern end of the Disko Gneiss Ridge per year for 2006-2013 varies between one and ten (Fig 4A). However, 2010 stands out with 27 detected earthquakes. The earthquake activity was particularly intense on 22 and 23 August (Fig 4B). The earthquakes ranged in magnitude from 1.9 to 3.2 with most

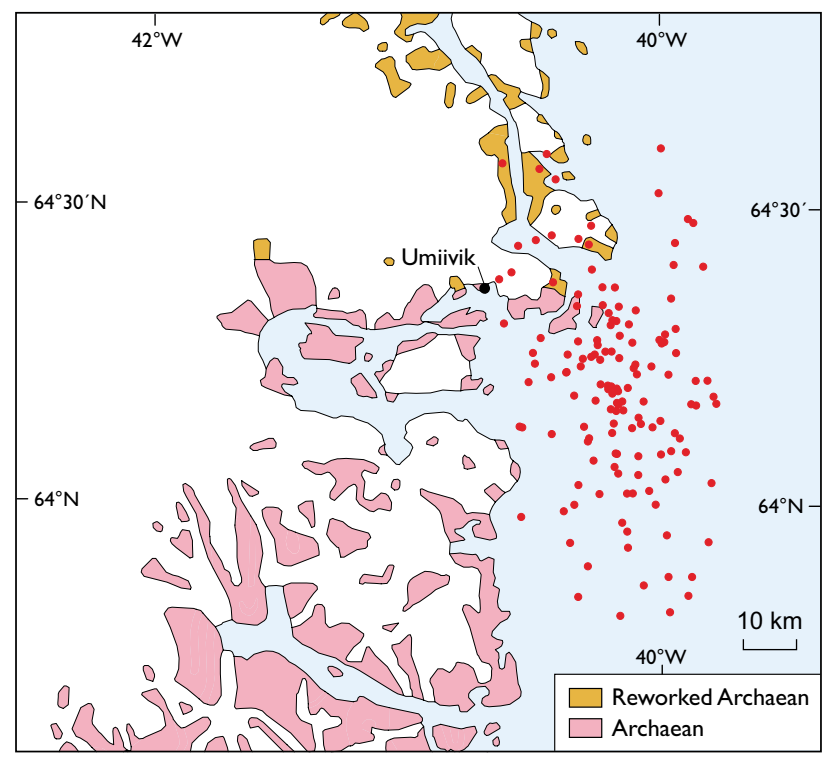

Fig. 3. The calculated epicentres for the swam earthquakes near Umiivik, on the South-East Greenland coast. 


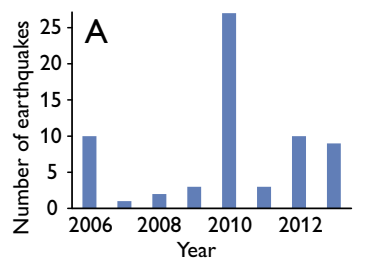

Disko

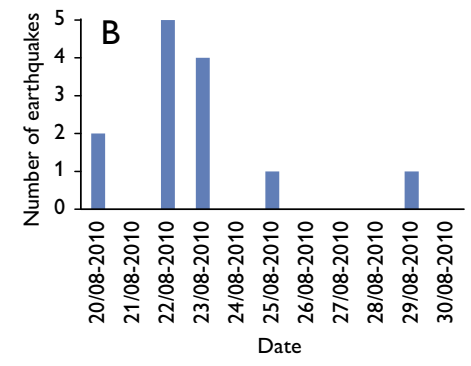

Fig. 4. A: Number of earthquakes per year for the period 2006-2013 around the location of the earthquake swarm on Disko. B: Number of earthquakes per day from 20 to 30 August 2010 in the same area.

clustering in the magnitude range between 2.2 and 2.8. The earthquake epicentres were spread out over a small area with the largest distance between two events being about $30 \mathrm{~km}$. This distance is within the uncertainty on the locations. The uncertainty on the epicentres is in the order of $10 \mathrm{~km}$ in $\mathrm{N}-\mathrm{S}$ direction and at least $50 \mathrm{~km}$ in $\mathrm{E}-\mathrm{W}$ direction. This is caused by the geometry of the network relative to the events with seismographs primarily located north and south of the epicentres. As Fig. 2 shows, the scatter in the epicentres was indeed largest in E-W direction.

The closest seismograph where all earthquakes were registered is located in Ilulissat (ILULI) $110-120 \mathrm{~km}$ away. The earthquakes were also registered in Nuugaatsiaq (NUUG) c. $220 \mathrm{~km}$ to the north, in Kangerlussuaq (SFJD) $320 \mathrm{~km}$ to the south and at the Summit ice camp (SUMG) $650 \mathrm{~km}$ towards the north-east. A few earthquakes were registered on a total of eight seismographs in Greenland, but most of them were registered in just four locations. The depth of the earthquakes is poorly determined, but appears to be shallow. A major challenge in determining the depth is the limited knowledge of the crustal velocity structure. The depth to Moho is known from receiver function studies (Dahl-Jensen et al. 2003), and the crustal density structure in the Disko area has been modelled from seismic and potential field data (Chalmers et al. 1999). Relocating the earthquakes with a fixed depth of $5 \mathrm{~km}$ does not reduce the distance between the epicentres significantly. However, the variation in time difference between the $P$-wave arrival and the $S$-wave arrival was less than $1.5 \mathrm{sec}$. indicating a small source region.

The north-south-oriented fault along the Disko Gneiss Ridge is a known zone of weakness, and the area is characterised by a moderate earthquake activity with no seasonal variation. In SE Finland earthquake swarms are observed to be related to the intrusion of water and gas into fractures working in concert with the local stress field (Uski et al. 2006). A similar mechanism is likely on Disko. As warm water is circulating in deep cracks all year round a seasonal variation is not expected. Some of the warm springs on Disko are radioactive (Kristensen 2006) containing radon from the basement. Radon is also observed near earthquake swarms in Finland, and radon gas is believed to play a minor role in triggering earthquake swarms in SE Finland (Uski et al. 2006).

\section{Earthquake swarm in South-East Greenland}

The east coast of Greenland is frequently shaken by small earthquakes. In Tasiilaq earthquakes are felt almost every year. Many small earthquakes are registered farther down the coast, but it is not known if any of these events can be felt as the area is not populated. Earthquake swarm activity was detected in January 2008 and in the spring of 2009 just off the coast near Umiivik. The earthquakes in the swarm range in magnitude from 1.8 to 3.8. In the years before and after the swarm period, the level of earthquake activity in the area range between 12 and 21 earthquakes per year (Fig. 5A). However, in 2008 and 2009 respectively 71 and 114 earthquakes were registered. The earthquakes occurred primarily in January and April 2008 and again from January to July 2009 (Fig. 5B).

The uncertainty on most of the epicentres is several hundred kilometres in both the N-S and E-W directions. This is a consequence of the earthquakes being detected primarily by only two seismographs (four phases in total) in Kangerlussuaq (SFJD) and at Summit (SUMG) $550 \mathrm{~km}$ and $1000 \mathrm{~km}$ from the epicentres. The distance between the seismographs and the epicentres is well-determined, but the direction is poorly constrained. After improvements had been made to the seismograph network, a larger earthquake with a magnitude of 3.6 occurred in the area on 13 October 2009. This earthquake was well-recorded at four locations: Narsarsuaq (NRS), Kangerlussuaq (SFJD), Ilulissat (ILULI) and Summit (SUMG) with an uncertainty of less than $10 \mathrm{~km}$ in N-S direction and less than $20 \mathrm{~km}$ in E-W direction. This earth-

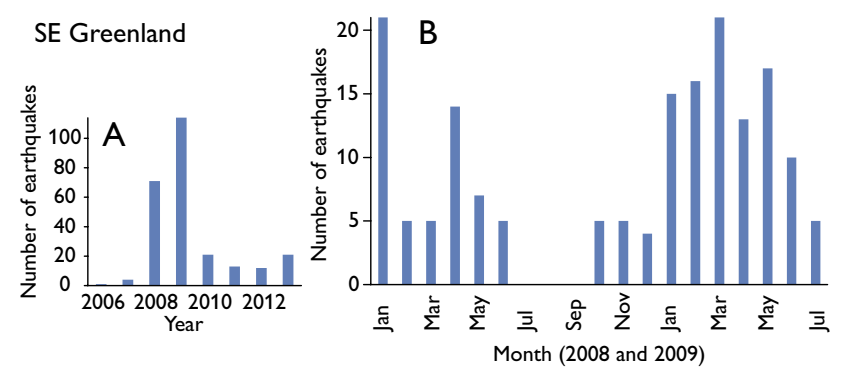

Fig. 5. A: Number of earthquakes per year for the period 2006-2013 around the location of the earthquake swarm at the SE Greenland coast. B: Number of earthquakes per month from January 2008 to July 2009 in the same area. 
quake is located near the centre of the cloud of epicentres, and it can be used to evaluate the relative locations of the swarm earthquakes.

The waveforms for the small earthquakes are very noisy, making a direct comparison difficult. Instead we examine the variation in time difference between the $P$-wave and $S$ wave arrival for individual earthquakes. Despite the epicentres being scattered over almost $100 \mathrm{~km}$ in N-S direction and $c .50 \mathrm{~km}$ in $\mathrm{E}-\mathrm{W}$ direction, the variation in $S-P$ time (i.e. the distance to the earthquake) at each seismograph station fluctuated only in rare cases by more than $1.5 \mathrm{sec}$. relative to the 13 October 2009 earthquake. The large scatter in epicentres is probably an artefact of the focal depth being unconstrained.

The Umiivik area marks a major geological transition between the relatively unreworked Archaean rocks to the south and rocks highly deformed in the Proterozoic to the north (Henriksen et al.2009). Offshore the existence of a failed rift arm was proposed by Hopper et al. (1998). The earthquake swarm was thus located close to two old geological boundaries. This is in good accordance with the general observations by Stykes (1978) that intraplate earthquakes indeed occur in old zones of weakness.

\section{Conclusion}

As shown by this initial search for earthquake swarms, the improvements to the seismograph network in Greenland enable us to better uncover and analyse swarms in the future. The swarms presented in this paper could not have been detected a decade ago. Intraplate earthquake swarms can contribute to the understanding of geological processes currently at work near old geological boundaries in remote areas. Both swarms presented here were active near old geological boundaries. The swarm on Disko is located at the southern end of the Disko Gneiss Ridge where a large fault runs through the island. Circulating water in deep cracks may possibly play a role. The SE Greenland swarm is located close to a major geological boundary between reworked and unreworked Archaean rocks. Furthermore, the swarm is close to the proposed location of a failed rift arm in the Atlantic. Finding earthquake swarms close to old, major, geological boundaries is well in accordance with the literature. The earthquake swarms presented in this paper are not associated with known sedimentary basins such as the swarms described in Gregersen (1979). This indicates a diversity of swarm sources in Greenland. Further work will be carried out on the earthquake swarms in Greenland and data from temporary and Canadian seismographs will be included in the analysis.

\section{Acknowledgement}

The data were collected and distributed by the GLISN project and its members, www.glisn.info.

\section{References}

Atakan, K., Lindblom, C.D. \& Havskov, J. 1994: Earthquake swarm in Steigen, northern Norway: an unusual example of intraplate seismicity. Terra Nova 6, 180-194.

Chalmers, J.A., Pulvertaft, T.C.R., Marcussen, C. \& Pedersen, A.K. 1999: New insight into the structure of the Nuussuaq Basin, central West Greenland. Marine and Petroleum Geology 16, 197-224.

Dahl-Jensen, T. et al. 2003: Depth to Moho in Greenland: receiver function analysis suggests two Proterozoic blocks in Greenland. Earth and Planetary Science Letters 205, 379-393.

Dahl-Jensen, T., Larsen, T.B., Voss, P.H. \& the GLISN group 2010: Greenland ice sheet monitoring network (GLISN): a seismological approach. Geological Survey of Denmark and Greenland Bulletin 20, 55-58.

Gregersen, S. 1979: Intraplate earthquake swarms in Greenland and adjacent continental regions. Nature 281, 661-662.

Henriksen, N., Higgins, A.K., Kalsbeek, F. \& Pulvertaft, T.C.R. 2009: Greenland from Archaean to Quaternary. Descriptive text to the Geological map of Greenland 1:2 500000.2 nd edition. Geology of Greenland Survey Bulletin 18, $126 \mathrm{pp}$.

Hjelme, J. 1996: History of seismological stations in Denmark and Greenland. In: Wahlström, R. (ed.): Seismograph recording in Sweden, Norway - with arctic regions, Denmark - with Greenland, and Finland. Proceedings from the Uppsala Wiechert Jubilee Seminar, 49-57. Uppsala: Seismological Department, Uppsala University, Sweden.

Hopper, J.R., Lizarralde, D. \& Larsen, H.C. 1998: Seismic investigations offshore South-East Greenland. Geology of Greenland Survey Bulletin 180, 145-151.

Kristensen, R.M. 2006: De varme kilder. In: Bruun, L. et al. (eds): Arktisk Station 1906-2006, 310-315. Copenhagen: Rhodos.

Ma, S. \& Eaton, D.W. 2009: Anatomy of a small earthquake swarm in southern Ontario, Canada. Seismological Research Letters 80, 214223, http://dx.doi.org/10.1785/gssrl.80.2.214

Ottemöller, L., Voss, P.H. \& Havskov, J. 2011: SeisAn earthquake analysis software for Windows, Solaris, Linux and MacOSX. University of Bergen.

Stykes, L.R. 1970: Earthquake swarms and sea-floor spreading. Journal of Geophysical Research 75, 6598-6611.

Stykes, L.R. 1978: Intraplate seismicity, reactivation of pre-existing zones of weakness, alkaline magmatism, and other tectonism postdating continental fragmentation. Reviews of Geophysics and Space Physics 16, 621-688.

Uski, M., Tiira, T., Korja, A. \& Elo, S. 2006: The 2003 earthquake swarm in Anjalankoski, south-eastern Finland. Tectonophysics 422, 55-69.

Authors' address

Geological Survey of Denmark and Greenland, Øster Voldgade 10, DK-1350 Copenhagen K, Denmark; E-mail: tbl@geus.dk 